\title{
IMPLEMENTATION OF ACTIVITY-BASED COSTING AND ACTIVITY-BASED VARIANCE ANALYSIS IN FOOD INDUSTRY
}

\author{
YIYYECEK SEKTÖRÜNDE FAALIYYT TABANLI MALIYYETLEME VE \\ FAALIYYET TABANLI SAPMA ANALIZZI UYGULAMASI
}

\author{
Zeliha KALDIRIM ${ }^{*}$ \\ Yusuf KALDIRIM ${ }^{* *}$ iD
}

\begin{abstract}
Activity-based costing assigns overheads to products with convenient drivers and makes costs of products visible on activities level. Activity-based variance analysis approaches reveal variances on product and activity level. Activity based costing and activitiybased variance analysis are tools for continuous improvement and cost management. This study aims to apply activity-based costing and activity-based variance analysis in food industry. First stage covers observation and data collection period. Implementation preiod starts with activity-based budgeting process. Then, overheads assigned to products following activity-based costing steps than using activity-based variance analysis approaches variances are calculated. Activity-based costing implementation results provided evidence that overheads consist important part of food costs. Activity-based variance analysis results revealed variances on activity and product level.
\end{abstract}

Keywords: Activity-based costing, activity-based variance analysis, cost management

JEL Classification: M41, M10, M49

Öz

Faaliyet tabanlı maliyetleme genel üretim giderlerini uygun dağıtım ölçüleri ile ürünlere yükleyerek, ürün maliyetlerinin faaliyetler düzeyinde görünür olmasını sağlamaktadır. Faaliyet tabanlı sapma analizi yaklaşımları, sapmaları ürünler ve faaliyetler düzeyinde ortaya koymaktadır. Faaliyet tabanlı maliyetleme ve faaliyet tabanlı sapma analizi sürekli iyileştirme ve maliyet yönetimi için önemli araçlardır. Bu çalışmada faaliyet tabanlı maliyetleme ve faaliyet tabanlı sapma analizinin yiyecek sektöründe uygulanması amaçlanmaktadır. İlk aşama gözlem ve veri toplama süreçlerini kapsamaktadır. İkinci aşama olan uygulama dönemi faaliyet tabanlı bütçeleme süreci ile başlamış sonrasında faaliyet tabanlı maliyetleme uygulama adımlarını takip ederek genel üretim giderleri yiyeceklere yüklenmiş ve faaliyet tabanlı sapma analizi

* Ph.D. Candidate, İstanbul University, Institute of Social Sciences, zelihabilmez@hotmail.com.

** Dr., Republic of Turkey Ministry of National Education, yusufkaldirim54@hotmail.com.

To cite this article: Kaldırım, Z. \& Kaldırım, Y. (2020). Implementation of activity of activity-based costing and activitybased variance analysis in food industry. Journal of Research in Business, 5(2), 174-192.

"Çalışmada Etik Kurul izni gerekmemektedir." 
yaklaşımları ile sapmalar hesaplanmıştır. Faaliyet tabanlı maliyetleme uygulama sonuçları, genel üretim giderlerinin yemek maliyetlerinin önemli bir kısmını oluşturduğunu göstermektedir. Faaliyet tabanlı sapma analizleri ise yemek ve faaliyet düzeyinde sapmaları ortaya koymuştur.

Anahtar Kelimeler: Faaliyet tabanlı maliyetleme, faaliyet tabanlı sapma analizi, maliyet yönetimi Jel Sinuflamasi: M41, M10, M49

\section{Introduction}

Cost management, product pricing, continuous improvement and sustainability of productivity are crucial processes for managers in global competitive business environment. Managers needs accurate and detailed cost information for true decisions. While, overheads were minor cost factor, direct labor and material expenses were main source of costs in the past (Cooper \& Kaplan, 1988). Traditional costing systems work well when direct costs consist major part of products. Today, direct labor and direct material costs are lower compared the past, overheads consist important part of product or service costs. Overheads are the black holes in traditional costing systems (Plowman, 2001). Traditional methods produce inaccurate and misleading (Gupta \& Galloway, 2003) results in the case of high overheads. Thus, traditional costing systems cannot effectively support decision making (Goebel, Marshal \& Locandar, 1990) and management process and may not answer todays requirements. In this direction, $\mathrm{ABC}$ emerged from requirement of accurate cost information (Cardoş \& Pete, 2011). ABC is beyond a product costing approach (Lere, 2000; Özbayrak, Akgün \& Türker, 2004). ABC described as promising decision support tool by Geri and Ronen (2005). Improving decision-making structure and rational resource utilization of enterprises in relation to new competition conditions is only possible with activity-based approach in costing. (Pazarçeviren \& Şahin, 2013).

$\mathrm{ABC}$ is a costing method. But, $\mathrm{ABC}$ alone is not a golden key to open lock of efficiency. Variance analysis is important tool as important as costing method to use resources effective and to support continuous improvement. Variance analysis should be in compatible with costing management systems. Activity-based variance analysis (ABVA) reveals variances based on products and activities level and produce convenient data in $\mathrm{ABC}$ environment and supports $\mathrm{ABC}$.

Geri \& Ronen (2005) state that ABC method is convenient for service sector. Restaurants are a part of service sector and labor-intensive. Competition is tough. Creating value is important. Restaurant industry historically uses simple approaches to price menu items and, takes into consider just direct food costs to calculate price of menu items. Labor costs consist important part of operating expenses. Overhead expenses are around half of the restaurant costs and labor costs are important part of total costs. Simple approaches, focusing on just food costs or variable costs for pricing may not take into consider overhead and operating costs, such as, labor, utilities, energy, electricity, rent and other fixed costs (Raab, Mayer \& Shoemaker, 2009; Raab \& Zemke, 2016). In this scope, applying convenient costing method in a competitive environment is crucial for restaurant industry. Raab \& Zemke (2016) state that if product and resource consumption is not correlated with traditional cost 
allocation methods, $\mathrm{ABC}$ is convenient and food industry is a good sample for this approach. Moving from these motivations aim of the study is to apply $A B C$ and ABVA in food industry.

Plenty of studies conducted to implement $\mathrm{ABC}$ in different industries. In restaurant industry studies are limited. These studies demonstrated feasibility and the importance of $\mathrm{ABC}$ for reliable and convenient cost information and profitability analysis (Raab, 2003; Raab, Mayer \& Ramdeen, 2005; Raab, Shoemaker \& Mayer, 2007; Annaraud, Raab \& Schrock, 2008; Raab, Mayer \& Shoemaker, 2009; Ben Hadj Salem-Mhamdia \& Bejar Ghadhab, 2012; Linassi, Alberton \& Marinho 2016). Study one of the few studies implementing activitiy-based costing in the food industry. ABC is powerful cost management method. But, effective cost management requires detailed and deeply analysis. This makes necessary to take the analysis one step further. In this framework, ABVA comes to fore front. In the food sector, there is no study as well as very limited numbers of studies implementing activity-based variance analysis in the literature (Sar1, 2015). Study fills this gap and contributes to literature by implementing activity-based costing and activity-based variance analysis together and brings a new addition to cost management in food industry.

Study designed as follows: next section includes literature on $\mathrm{ABC}$. The third section explained ABVA approaches and calculations. Fourth section explains the implementation process, variance calculations and reveals implementations results of $A B C$ and ABVA in a self-service restaurant. Results revealed that overheads consist important part of food costs. ABVA results revealed variances activity and foods level.

\section{Activity-Based Costing}

ABC, created bases by George Staubus (1971) entered the literature in 1980's with Harvard Business School cases and articles (Kaplan \& Anderson, 2003). ABC gained popularity and adopted by many firms from different industries in 1990's and than (Stratton et al., 2009). ABC designed to produce more accurate product cost information so that managers focus on the products and processes to increase profitability (Cooper \& Kaplan, 1988). Main concept is "activity". Activity refers as any separate task that causes cost to produce a product or service (Ittner, 1999).

Stratton et al. (2009) state that $\mathrm{ABC}$ is effective cost management and profitability measurement method. According to Özbayrak, Akgün \& Türker (2004) ABC makes costs visible and provides to reveal how costs passed to products. ABC focuses on flows and processes (Gupta \& Galloway, 2003). In ABC, costs can not be explained just volume (Lere, 2000) or other artificial (Gupta \& Galloway, 2003) volume-driven measures. Product or service costs arise from activity-specific measures, which called activity cost driver, consumed by products or services during production process such as processing time, number of transactions, units tested etc. Activity cost drivers take into consider cause and effect relationship. In this framework, ABC uses realistic (Gupta \& Galloway, 2003) and more sophisticated approach to assign overheads to activities and products compared to traditional methods (Cooper \& Kaplan, 1988), which use volume-driven allocation bases (Cooper \& Kaplan, 1992). 
$\mathrm{ABC}$ has an unique role to define value-added and non-value-added activities (Ittner, 1999) and to increase productivity. But, as stated by Cooper and Kaplan (1991) decreasing resource consumption is first round. Sustainability of $\mathrm{ABC}$ gains are based on balancing between resource consumption and spending. (Cooper \& Kaplan, 1991).

ABC includes some weaknesses. Cooper \& Kaplan (1988) state that excess capacity should not be charged to products. Although ABC subjected to debates among practitioners and academics, some surveys and academic studies revealed, positive financial effect (Kennedy \& Affleck-Grawes, 2001; Cagmin \& Bouwman, 2002), perceived importance and reliability of ABC (Statron et al., 2009).

Cooper \& Kaplan (1988) stated that "simplistic approaches generate distorted product cost information and we present an alternative approach as called $\mathrm{ABC}$ ”. They explained why product costs distorted and they explained $\mathrm{ABC}$ system designing process and documented how $\mathrm{ABC}$ changes product profitability. After than studies implemented $\mathrm{ABC}$ and documented gains of $\mathrm{ABC}$ in different industries from manufacturing to service. In studies for food industry, Raab (2003) developed $\mathrm{ABC}$ model for restaurant in the USA and concluded that $\mathrm{ABC}$ is feasible for product costing for restaurants. Model also, examined by Raab, Mayer \& Ramdeen (2005) in Hong Kong China. Similar to Raab (2003) findings confirmed that ABC is feasible for product costing. In addition these studies, Raab Shoemaker \& Mayer (2007) created an ABC model and applied in a restaurant. Results revealed that $\mathrm{ABC}$ is convenient method to establish accurate cost information. Annaraud, Raab \& Schrock (2008) revealed that ABC is an important tool for cost and profitability analysis in a quick service restaurant. Raab, Mayer \& Shoemaker (2009) demonstrated that ABC-based approach produces different cost information from traditional methods. Results confirmed that $\mathrm{ABC}$ may be useful method in restaurant industry for cost management because of high labor costs and various resource consumption. Ben Hadj Salem-Mhamdia \& Bejar Ghadhab (2012) concluded that ABC is a feasible method for product costing and $\mathrm{ABC}$ with value management improves decision making process. Linassi, Alberton \& Marinho (2016) examined ABC and menu engineering Findings revealed that most menu items generate negative operating profit in $\mathrm{ABC}$. Researchers stated that results confirm previous research outcomes and menu engineering with $\mathrm{ABC}$ is effective tool than alone menu engineering for restaurants.

\section{Activity-Based Variance Analysis}

Overhead variance analysis aims to reveal causes of variances and enables to evaluate performance by comparing actual and planned costs (Horngren, Srikant \& Rajan al., 2012). Traditional variance analysis reveals just total variances. ABVA approaches emerged, owing to traditional variance analysis remained incapable to reveal overhead variances in $A B C$ environment. ABVA provides to calculate variances on the basis of products, activities as being different from traditional variance analysis approaches (Sarı \& Ülker, 2016). Sustainability of continuous improvement and efficiency required dynamic approach, which contains efficiency analysis of activities and balancing resource 
consumption and spending. In this framework, ABVA is an important tool for continuous improvement and cost management.

Activity-based variance calculations reveal more convenient an accurate result in $\mathrm{ABC}$. According to Mak and Roush (1994) activity based variance analysis is important for cost control in organizations adopted $\mathrm{ABC}$. $\mathrm{ABC}$ increases importance of activity based variance analysis for cost control.

Malcom (1991) emphasized that traditional standard cost approaches focus on labor-based cost drivers and traditional variance analysis approaches are not useful, do not support productivity and decrease usefulness of other accounting reports. According to Malcom (1991) cost-driver based variable budget systems must gain importance. In this framework, Malcom (1991) focused on price and quantity variances with activity-based flexible budget. Malcom (1991) price and quantity variances reveal variances from variable cost perspective. Price variance is difference between actual variable activity cost and flexible budget calculated based on actual cost driver. Quantity variance is difference between flexible budget calculated based on actual cost driver and flexible budget calculated based on standard quantity.

\begin{tabular}{l|l|l} 
Price Variance $=$ & $\begin{array}{l}\text { Actual Variable Activity Cost - } \\
\text { Quantity Variance }=\end{array}$ & $\begin{array}{l}\text { Flexible Budget (Based on Actual Quantity of } \\
\text { Cost Driver) }\end{array}$ \\
$\begin{array}{l}\text { Flexible Budget (Based on Actual - Quantity } \\
\text { Of Cost Driver) }\end{array}$ & $\begin{array}{l}\text { Flexible Budget (Based on Standard Quantity of } \\
\text { Cost Driver) }\end{array}$
\end{tabular}

Cooper \& Kaplan (1992) state that the cost of supplied resources is fixed in short-run otherwise quantity of used resources by activities may change based on output level. In this framework measurement of difference between the cost of resources used to perform activities and the cost of resources supplied is important indicator, which is called unused capacity. Unused capacity equals the difference in costs between activity availability and activity usage (Cooper \& Kaplan, 1992).

Unused Capacity Variance $=$ Activity Availability - Activity Usage

Cost of Unused Activity $=$ Cost of Activity Supplied - Cost of Activity Used

The calculation is similar to traditional volume variance but, there are significant differences. (Cooper \& Kaplan, 1992). While, traditional volume variance calculated on the basis of departments or fabric, unused capacity is calculated for each activity (Mak \& Roush, 1994). While volume variance reveals non-value added costs, unused capacity reveals the improvements in reducing non-value added cost. Thus, managers should modify demand for activity until unused capacity variance being equal to traditional volume variance (Hansen, Mowen \& Guan, 2009). Managers may use unused capacity data to justify resource supply based on fluctuations on output level in the future. Resources and spending may be balanced. Thus, resources can be used productively according to philosophy of ABC. 
Cooper \& Kaplan (1992) also suggest to comparison between actual and budgeted expenses (Cooper \& Kaplan, 1992) similar to traditional budget variance calculated for fixed overheads (Mak \& Roush, 1994).

\section{Budget Variance $=$ Actual Activity Cost - Budgeted Activity Cost}

Mak \& Roush (1994) state that flexible budgets and variance analysis are important on cost control and performance evaluation in $\mathrm{ABC}$ environment and $\mathrm{ABC}$ increases value of flexible budgets and variance analysis. According to Mak \& Roush (1994) separating fixed and variable cost in the short-term is important for cost control and performance evaluation. In this framework, Mak \& Roush (1994) propose price and efficiency variances for variable activity costs and budget, capacity variances for fixed activity costs.

\begin{tabular}{|c|c|c|}
\hline $\begin{array}{l}\text { Spending } \\
\text { (Price) }= \\
\text { Variance }\end{array}$ & Actual Variable Costs - & $\begin{array}{l}\text { Flexible Budget (Variable Cost } \\
\text { Based on Actual Quantity of Cost Driver) }\end{array}$ \\
\hline $\begin{array}{l}\text { Efficiency } \\
\text { Variance }=\end{array}$ & $\begin{array}{l}\text { Flexible Budget (Variable } \\
\text { CostBased on Actual - } \\
\text { Quantity of Cost Driver) }\end{array}$ & $\begin{array}{l}\text { Flexible Budget (Variable Cost Based } \\
\text { on Standard Quantity of Cost Driver) }\end{array}$ \\
\hline $\begin{array}{c}\text { Budget } \\
\text { Variance }=\end{array}$ & Actual Fixed Cost - & $\begin{array}{l}\text { Budgeted Fixed Cost (Based on } \\
\text { Availability of Cost Driver) }\end{array}$ \\
\hline $\begin{array}{l}\text { Capacity } \\
\text { Variance = }\end{array}$ & $\begin{array}{l}\text { Budgeted Activity Spending } \\
\text { (Based on Availability of - } \\
\text { Cost Driver) }\end{array}$ & $\begin{array}{l}\text { Budgeted Activity Usage (Based } \\
\text { on Standard Quantity of Cost Driver) }\end{array}$ \\
\hline
\end{tabular}

Budget variance reveals difference between actual and budgeted fixed activity costs similar to the traditional budget variance. Capacity variance reveals non-value added cost of activity. Thus, capacity variance provides important information to reduce non-value added costs in the long-run (Mak \& Roush, 1994).

According to Hansen \& Mowen (2006) in activity management environment analysing variances from fixed and variable cost perspective provides more detailed information to determine source of variances. In this framework Hansen \& Mowen (2006) suggest to calculate fixed and variable budget variances.

$\begin{array}{lll}\begin{array}{l}\text { Fixed } \\ \text { Budget }=\text { Variance }\end{array} & \text { Actual Fixed Cost }- & \text { Budgeted Fixed Cost } \\ \text { Variable Budget }=\text { Variance } & \text { Actual Variable Cost }- & \begin{array}{l}\text { Budgeted Variable Cost (Based } \\ \text { On Actual Quantity of Cost Driver) }\end{array}\end{array}$

As explained above there are several variances in the scope of ABVA. Several studies aimed to explain and reveal the importance of ABVA approaches with hypothetical case studies (Ruhl, 1995; Özbayrak, Akgün \& Türker, 2004; Parlakkaya, 2004; Kren, 2008, Horngren, Srikant \& Rajan, 2012). Sarı (2015) implemented $\mathrm{ABC}$ and used ABVA analysis approaches in a manufacturing company and analysed the results on activity and product level. 


\section{Implementation of Activity Based Costing and Activity-Based Variance Analysis In Food Industry}

Aim of the study is to implement $A B C$ and ABVA in food industry. In this context, case study carried out in a self-service restaurant. Restaurant menu includes 20 menu items comprising soups, main foods, deserts and salads, which services on weekdays and Saturday.

Data were collected from restaurant owners workers, observations, case reports, accounting data and standard receipts of menu items. January 2018 and February 2018 are observation periods, March 2018 is implementation period.

\subsection{Implementation of Activity-Based Costing}

Products are output of activities. According to $\mathrm{ABC}$ products consume activities, activities consume resources. Following this cycle, $\mathrm{ABC}$ aims to assign cost of resources via resource drivers to activities and cost of activities to products via activity drivers to calculate the most convenient product cost.

$\mathrm{ABC}$ process starts with identifying activities. In this framework in the first step, identified activities based on observations and interviews. Table 1 shows determined activities in the restaurant.

Table 1: Self-Service Restaurant Activities

\begin{tabular}{c}
\hline Preparation \\
Cooking \\
Order and Dish Assembly \\
Payment \\
Cleaning Table \\
Washing \\
Service \\
Kitchen General \\
\hline
\end{tabular}

Study reveals indirect labor resource cost allocation to service activity, allocation cost of service activity cost pool to foods and ABVA calculations for a main food (forest kebab) and a desert (pumpkin desert).

Second step is to assign the resource costs to activities and forming activity cost pools via cost drivers but, beginning of this process should be determined overheads. Restaurant overheads are labor cost, rent, depreciation, natural gas, electricity, water, business material and heating. Indirect labor costs contains salaries of workers (1 kitchen staff, 5 restaurant staffs, 1 case staff, 1 dish assembly staff). Business material contains cleaning materials used for washing and cleaning activities. Overheads determined as monthly. 
The most important point at this stage is to identify the most convenient resource drivers consumed by activities. Table shows resource and identified resource drivers.

Table 2: Resources and Resource Drivers

\begin{tabular}{ll}
\hline Resource & Resource Driver \\
\hline Indirect Labor & Indirect Labor Hour (Hour) \\
Rent & Area $\left(\mathrm{m}^{2}\right)$ \\
Depreciation & Depreciation Amount (TRY) \\
Natural Gas & Consumption $\left(\mathrm{m}^{3}\right)$ \\
Electricity & Consumption $(\mathrm{Kwh})$ \\
Water & Utilization Rate $(\%)$ \\
Business Material & Utilization Rate $(\%)$ \\
Heating & Area $\left(\mathrm{m}^{2}\right)$ \\
\hline
\end{tabular}

At the beginning of third step resource drivers, resource allocation rates calculated. Then, determined cost driver consumption of each activity and assigned costs to activities via resource drivers and formed activity cost pools. Activity cost driver consumptions determined based on observations and face to face negotiations. Table 3 shows calculation of resource allocation rate for indirect labor cost. Table 4 shows allocation of indirect labor cost to service activity cost pool.

Table 3: Resource Allocation Rate

\begin{tabular}{|c|c|c|c|c|}
\hline Resource & Resource Driver & $\begin{array}{l}\text { Resource Cost } \\
\text { (TRY) } \\
\text { (A) }\end{array}$ & $\begin{array}{c}\text { Total Resource } \\
\text { Driver (Hour) } \\
\text { (B) }\end{array}$ & $\begin{array}{c}\text { Resource Allocation Rate } \\
\text { (TRY/Hour) } \\
\text { (A/B) }\end{array}$ \\
\hline Indirect Labor & $\begin{array}{c}\text { Indirect Labor } \\
\text { Hour }\end{array}$ & 16.250 & 1.300 & 12.50 \\
\hline
\end{tabular}

Table 4: Allocation of Indirect Labor Resource Cost To Service Activity

\begin{tabular}{ccccc}
\hline & Activity Cost & Resource Driver \\
Driver & $\begin{array}{c}\text { Resource } \\
\text { Consumption (Hour) }\end{array}$ & $\begin{array}{c}\text { Cost Of Activity Cost Pool } \\
\text { Allocation Rate } \\
\text { (TRY/Hour) }\end{array}$ & $\begin{array}{c}\text { For Indirect Labor Cost } \\
\text { (TRY) }\end{array}$ \\
Service & Service Time & (A) & (B) & $($ A X B) \\
\hline
\end{tabular}

Indirect labor cost of service activity cost pool is 4.550 TRY. In similar approach other resource costs assigned to service activity. Total cost of service activity cost pool is 13.894,65 TRY. In the next step determined activity cost drivers and activity cost driver consumption of each cost object by taking 
into consider cause and effect relationship in accordance with to logic of $\mathrm{ABC}$. Table 5 shows activity cost drivers used to assign cost of activities to costs object from cost pools.

Table 5: Activities and Activity Cost Drivers

\begin{tabular}{ll}
\hline Activity & Activity Driver \\
Preparation & Preparation Time (Minute) \\
Cooking & Cooking Time (Minute) \\
Order and Dish Assembly & Order and Dish Assembly Time (Minute) \\
Payment & Payment Time (Minute) \\
Cleaning Table & Cleaning Time (Minute) \\
Washing & Cleaning Time (Minute) \\
Service & Service Time (Minute) \\
Kitchen General & Preparation Time + Cooking Time (Minute) \\
\hline
\end{tabular}

In the next step, allocation rates were calculated to assign cost of activity cost pools to cost objects. Then, total overhead of each cost object was calculated. Following, unit overhead of each cost object was calculated. Activities and activity cost driver consumptions of each cost object were determined by face to face negotiations and observations. Table 6 shows calculation of service activity cost pool allocation rate.

Table 6: Activity Cost Pool Allocation Rate

\begin{tabular}{|c|c|c|c|c|}
\hline Activity Cost Pool & Activity Cost Driver & $\begin{array}{c}\text { Cost Of Activity } \\
\text { Cost Pool (TRY) } \\
\text { (A) }\end{array}$ & $\begin{array}{l}\text { Total Activity Driver } \\
\text { (Minute) } \\
\text { (B) }\end{array}$ & $\begin{array}{c}\text { Activity Cost Pool } \\
\text { Allocation Rate (TRY/ } \\
\text { Min) } \\
\text { (A/B) }\end{array}$ \\
\hline Service & Service Time & $13.894,65$ & 107.549 & 0,1292 \\
\hline
\end{tabular}

After calculation of allocation rates, unit overheads were calculated. Table 7 shows calculation of unit overhead rates.

Table 7: Indirect Labor Cost Unit Overhead Rate

\begin{tabular}{|c|c|c|c|c|c|}
\hline Cost Object & $\begin{array}{l}\text { Activity Cost Driver } \\
\text { Consumption } \\
\text { (Minute) } \\
\text { (A) }\end{array}$ & $\begin{array}{c}\text { Allocation Rate } \\
\text { (TRY/Min.) } \\
\text { (B) }\end{array}$ & $\begin{array}{c}\text { Total Overhead } \\
\text { (TRY) } \\
\text { C(AXB) }\end{array}$ & $\begin{array}{c}\text { Production } \\
\text { Amount (Unit) } \\
\text { (D) }\end{array}$ & $\begin{array}{l}\text { Unit Overhead Rate } \\
\text { (TRY/Unit) } \\
\text { (C/D) }\end{array}$ \\
\hline Forest Kebab & 5.940 & 0,1292 & 767,45 & 660 & 1,1628 \\
\hline $\begin{array}{c}\text { Pumpking } \\
\text { Desert }\end{array}$ & 3.500 & 0,1292 & 452,20 & 700 & 0,6446 \\
\hline
\end{tabular}


Pumpkin Desert Cost Driver Consumption $=5 \mathrm{~min} . /$ unit $\mathrm{x} 700$ unit $=3500 \mathrm{~min}$.

Figure 1 shows the implementation process of $\mathrm{ABC}$. Finally, unit costs were calculated. Table 8 shows unit direct costs, overheads and total unit cost of foods.

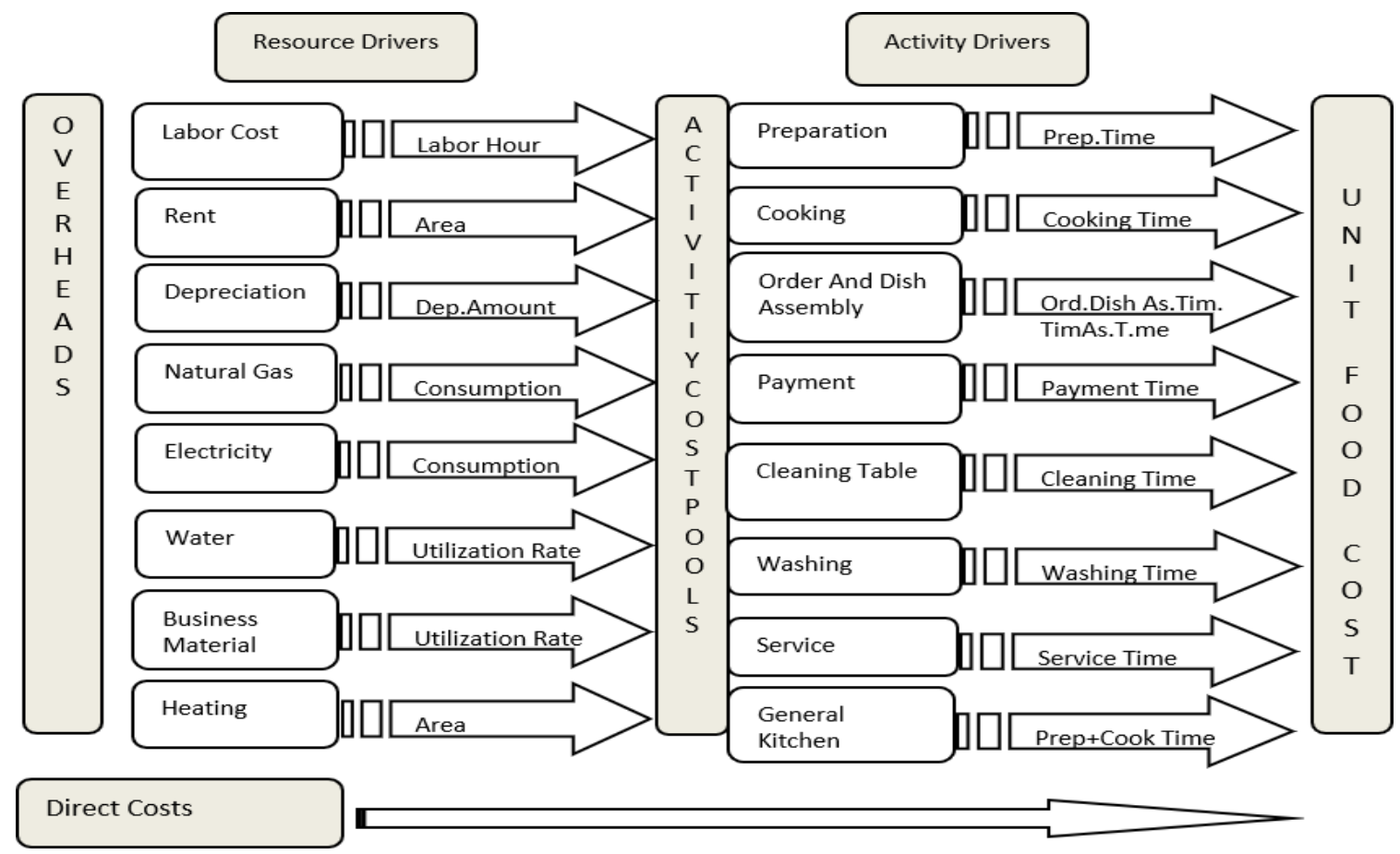

Figure 1: Activity-Based Costing Process

Table 8: Unit Costs of Foods

\begin{tabular}{ccc}
\hline Cost Item & $\begin{array}{c}\text { Forest Kebab } \\
(\text { TRY) }\end{array}$ & Pumpkin Desert (TRY) \\
Direct Material & 6,24 & 3,87 \\
Direct Labor & 0,71 & 0,50 \\
Overhead & 4,10 & 3,33 \\
Unit Cost & 11,05 & 7,70 \\
\hline
\end{tabular}

\subsection{Implementation of Activity-based Budgeting}

ABVA requires activity-based budgeting $(A B B)$. $A B B$ is reverse process of $A B C$. $A B B$ process starts with sales budget based on demand forecast. The second step is to define budgeted activity consumption amount of each cost object. Third step is to define resource consumption amount and resource cost of each activity. Table 9 shows sales forecast and calculation of budgeted indirect labor costs of cost objects. 
Table 9: Sales Forecasts and Service Activity Budgeted Indirect Labor Cost

\begin{tabular}{|c|c|c|c|c|c|c|}
\hline Cost Object & $\begin{array}{l}\text { Budgeted } \\
\text { Production } \\
\text { (Unit) } \\
\text { (A) }\end{array}$ & $\begin{array}{l}\text { Budgeted Unit } \\
\text { Service Time } \\
\text { (Minute) } \\
\text { (B) }\end{array}$ & $\begin{array}{l}\text { Budgeted } \\
\text { Activity } \\
\text { Driver } \\
\text { (Minute) } \\
\text { (AXB) }\end{array}$ & $\begin{array}{l}\text { Utility Rate* } \\
\text { (\%) } \\
\text { (C) }\end{array}$ & $\begin{array}{l}\text { Indirect Labor } \\
\text { Cost (TRY) } \\
\text { (D) }\end{array}$ & $\begin{array}{c}\text { Budgeted } \\
\text { Indirect Labor } \\
\text { Cost (TRY) } \\
\text { (CXD) }\end{array}$ \\
\hline Forest Kebab & 640 & 9 & 5760 & 5,35 & 4.550 & 243,43 \\
\hline $\begin{array}{l}\text { Pumpkin } \\
\text { Desert }\end{array}$ & 750 & 5 & 3750 & 3,48 & 4.550 & 158,34 \\
\hline Other & 10.960 & & 98.180 & 91,17 & 4.550 & $4,148,23$ \\
\hline Total & 12.360 & & 107.690 & 100 & 4.550 & 4.550 \\
\hline
\end{tabular}

*Utility Rate Calculated by dividing total budgeted activity driver to budgeted activity driver.

Table 10 shows budgeted resource costs calculated based on budgeted production of forest kebap and pumpkin desert.

Table 10: Service Activity Budgeted Resource Costs (TRY)

\begin{tabular}{ccccc}
\hline Resource & $\begin{array}{c}\text { Food } \\
\text { Forest Kebab } \\
\text { (TRY }\end{array}$ & $\begin{array}{c}\text { Pumpkin Desert } \\
(\text { TRY })\end{array}$ & $\begin{array}{c}\text { Other } \\
(\text { TRY })\end{array}$ & $\begin{array}{c}\text { TOTAL } \\
\text { (TRY) }\end{array}$ \\
Indirect Labor & 243,43 & 158,34 & $4.148,23$ & 4.550 \\
Rent & 421,21 & 274,22 & $7.179,57$ & 7.875 \\
Depreciation & 47,71 & 31,06 & 813,23 & 892 \\
Electricity & 15,12 & 9,85 & 257,77 & 282,74 \\
Heating & 14,74 & 9,60 & 251,29 & 275,63 \\
Total & 742,21 & 483,07 & $12.650,09$ & $13.875,37$ \\
\hline
\end{tabular}

Table 11 shows calculation of service activity budgeted cost pool allocation rate. Allocation rate used to calculate budgeted food unit overhead rate and also, activity based variance calculations requires budgeted allocation rates.

Table 11: Budgeted Activity Cost Pool Allocation Rate

\begin{tabular}{|c|c|c|c|c|}
\hline $\begin{array}{c}\text { Activity Cost } \\
\text { Pool }\end{array}$ & $\begin{array}{c}\text { Activity Cost } \\
\text { Driver }\end{array}$ & $\begin{array}{c}\text { Budgeted Cost Of } \\
\text { Activity Cost Pool (TRY) } \\
\text { (A) }\end{array}$ & $\begin{array}{l}\text { Total Budgeted Activity } \\
\text { Cost Driver (Minute) } \\
\text { (B) }\end{array}$ & $\begin{array}{l}\text { Activity Cost Pool } \\
\text { Budgeted Allocation } \\
\text { Rate (TRY/Min.) } \\
\text { (C) }\end{array}$ \\
\hline Service & Service Time & 13.87.37 & 107.690 & 0,1288 \\
\hline
\end{tabular}


Table 12 shows budgeted unit overhead rate for forest kebab and pumpkin desert.

Table 12: Budgeted Unit Overhead Rate

\begin{tabular}{cccccc}
\hline Cost Object & $\begin{array}{c}\text { Activity Cost Driver } \\
\text { Consumption (Min.) }\end{array}$ & $\begin{array}{c}\text { Allocation Rate } \\
\text { (TRY/Min.) }\end{array}$ & $\begin{array}{c}\text { Total Overhead } \\
\text { (TRY) }\end{array}$ & $\begin{array}{c}\text { Production } \\
\text { Amount (Unit) } \\
\text { (A) })\end{array}$ & $\begin{array}{c}\text { Unit Overhead } \\
\text { Rate (TRY/Unit) } \\
\text { (C/D) }\end{array}$ \\
$\begin{array}{c}\text { Forest Kebab } \\
\begin{array}{c}\text { Pumpking } \\
\text { Desert }\end{array}\end{array}$ & 5760 & 0,1288 & 742,1499 & 640 & 1,1596 \\
\hline
\end{tabular}

Forest Kebap Cost Driver Consumption $=9$ min. $/$ unit $x 660$ unit $=5940 \mathrm{~min}$.

Pumpkin Desert Cost Driver Consumption $=5$ min./unit $x 700$ unit $=3500$ min.

Table 13 shows unit budgeted food costs.

Table 13: Budgeted Food Costs

\begin{tabular}{ccc}
\hline Cost Item & Forest Kebab (TRY) & Pumpkin Desert (TRY) \\
Direct Material & 6,10 & 3,88 \\
Direct Labor & 0,80 & 0,46 \\
Overhead & 4,10 & 3,25 \\
Unit Cost & 11,00 & 7,79 \\
\hline
\end{tabular}

ABVA requires variable and fixed cost allocation rate of each activity. Therefore, variable and fixed costs were determined for each activity and variable and fixed cost allocation rates were calculated. Table 14 shows variable and fixed resource costs and overhead rates of service activity.

Table 14: Service Activity Actual and Budgeted Variable and Fixed Costs, Allocation Rates

\begin{tabular}{ccccc}
\hline \multirow{2}{*}{ Resource } & \multicolumn{2}{c}{ ACTUAL } & \multicolumn{2}{c}{ BUDGETED } \\
\cline { 2 - 5 } & Variable Resource & Fixed Resource & Variable Resource & Fixed Resource \\
Indirect Labor & Cost & Cost & Cost & Cost \\
Rent (TRY) & - & 4550 & - & 4550 \\
Depreciation (TRY) & - & 7875 & - & 7875 \\
Electricity (TRY) & - & 892 & - & 892 \\
Heating (TRY) & 278,95 & - & 282,74 & - \\
Total (TRY) & 299,25 & - & 275,63 & - \\
Total Activity Driver (Min.) & 107.549 & 13.317 & 558,37 & 13.317 \\
Allocation Rate (TRY/Min.) & 0,0054 & 107.549 & 107.690 & 107.690 \\
\hline
\end{tabular}




\subsection{Implementation of Activity-Based Variance Analysis}

In the scope of ABVA budget, unused capacity, price, quantity, fixed budget, variable budget, spending, efficiency, budget and capacity variances were calculated.

Table 15 shows calculation of budget and unused capacity variances. While budgeted activity cost is lower than actual activity cost for forest kebab, it is reverse for pumpkin desert. Variance is favorable for pumpkin desert, unfavorable for forest kebab. Favorable variance on pumpkin desert arises from being lower of actual output level than budgeted output level (see table 7 and 12). Otherwise, increased output level caused the increase on actual activity cost of forest kebab.

Unused capacity variance is favorable for forest kebap. Favorable variance reveals that all available resources are used. Because of decreasing output level compared to budgeted level, variance is unfavorable on pumpkin desert. Unfavorable variance refers that available resources not used fully on pumpkin desert.

Table 15: Budget Variance and Unused Capacity Variance

\begin{tabular}{|c|c|c|c|c|c|c|c|c|c|}
\hline \multicolumn{4}{|c|}{ BUDGET VARIANCE } & \multicolumn{5}{|c|}{ UNUSED CAPACITY VARIANCE } & \multirow[b]{2}{*}{$\begin{array}{c}\text { Unused } \\
\text { Capacity } \\
\text { Variance } \\
(\mathrm{TRY})(\mathrm{B}-\mathrm{E})\end{array}$} \\
\hline $\begin{array}{c}\text { Cost } \\
\text { Object }\end{array}$ & $\begin{array}{c}\text { Actual } \\
\text { Cost of } \\
\text { Activity } \\
\text { Cost } \\
\text { Pool (TRY) } \\
\text { ( A) }\end{array}$ & $\begin{array}{l}\text { Budgeted } \\
\text { Cost of } \\
\text { Activity Cost } \\
\text { Pool (TRY) } \\
\text { (B) }\end{array}$ & $\begin{array}{c}\text { Budget } \\
\text { Variance } \\
(\mathrm{TRY})(\mathrm{A}-\mathrm{B})\end{array}$ & $\begin{array}{c}\text { Cost } \\
\text { Object }\end{array}$ & $\begin{array}{c}\text { Budgeted Cost } \\
\text { of Activity } \\
\text { Cost Pool } \\
\text { (TTRY) (B) }\end{array}$ & $\begin{array}{c}\text { Budgeted } \\
\text { Overhead } \\
\text { Rate (TRY) } \\
\text { (C) }\end{array}$ & $\begin{array}{l}\text { Actual } \\
\text { Cost } \\
\text { Driver } \\
\text { (Minute) } \\
\text { (D) }\end{array}$ & $\begin{array}{c}\text { Used } \\
\text { Capacity } \\
(\mathrm{TRY}) \\
(\mathrm{E}=\mathrm{CXD})\end{array}$ & \\
\hline $\begin{array}{l}\text { Forest } \\
\text { Kebab }\end{array}$ & 767,41 & 742,15 & 25,26 & $\begin{array}{l}\text { Forest } \\
\text { Kebab }\end{array}$ & 742,15 & 0,13 & 5940 & 765,34 & $-23,19$ \\
\hline $\begin{array}{c}\text { Pumpkin } \\
\text { Desert }\end{array}$ & 452,18 & 483,17 & $-30,99$ & $\begin{array}{c}\text { Pumpkin } \\
\text { Desert }\end{array}$ & 483,17 & 0,13 & 3500 & 450,96 & 32,21 \\
\hline
\end{tabular}

Table 16 shows price and quantity variances. Price variance is unfavorable on both foods. Unfavorable variances arise from being higher of actual source cost than budgeted costs (see table 7 and 12). Quantity variance is unfavorable on forest kebab. Unfavorable variance results from difference between actual cost driver and standard cost driver (see table 7).

Table 16: Price and Quantity Variances.

\begin{tabular}{|c|c|c|c|c|c|c|c|}
\hline \multicolumn{8}{|c|}{ Price Variance } \\
\hline $\begin{array}{c}\text { Cost } \\
\text { Object }\end{array}$ & $\begin{array}{c}\text { Actual } \\
\text { Variable } \\
\text { Cost } \\
\text { Allocation } \\
\text { Rate (TRY/ } \\
\text { Min.) (E) }\end{array}$ & $\begin{array}{l}\text { Actual Cost } \\
\text { Driver } \\
\text { (Minute) (D) }\end{array}$ & $\begin{array}{c}\text { Actual } \\
\text { Variable } \\
\text { Activity Cost } \\
\text { (TRY) } \\
\text { F(EXD) }\end{array}$ & $\begin{array}{l}\text { Budgeted } \\
\text { Variable Cost } \\
\text { Allocation } \\
\text { Rate (TRY/ } \\
\text { Min.) (G) }\end{array}$ & $\begin{array}{l}\text { Actual Cost } \\
\text { Driver } \\
\text { (Minute) (D) }\end{array}$ & $\begin{array}{c}\text { Flexible } \\
\text { Budget (Based } \\
\text { On Actual } \\
\text { Quantity of } \\
\text { Cost Driver) } \\
\text { (TRY) } \\
\text { H=(GXD) }\end{array}$ & $\begin{array}{c}\text { Price } \\
\text { Variance } \\
\text { (TRY) (F- } \\
\text { H) }\end{array}$ \\
\hline
\end{tabular}




\begin{tabular}{|c|c|c|c|c|c|c|c|}
\hline $\begin{array}{l}\text { Forest } \\
\text { Kebab }\end{array}$ & 0,0054 & 5940 & 32,08 & 0,0052 & 5940 & 30,89 & 1,19 \\
\hline $\begin{array}{l}\text { Pumpkin } \\
\text { Desert }\end{array}$ & 0,0054 & 3500 & 18,90 & 0,0052 & 3500 & 18,20 & 0,70 \\
\hline \multicolumn{8}{|c|}{ Quantity Variance } \\
\hline $\begin{array}{c}\text { Cost } \\
\text { Object }\end{array}$ & $\begin{array}{l}\text { Budgeted } \\
\text { Variable } \\
\text { Cost } \\
\text { Allocation } \\
\text { Rate (TRY/ } \\
\text { Min.) (G) }\end{array}$ & $\begin{array}{l}\text { Actual Cost } \\
\text { Driver } \\
\text { (Min) (D) }\end{array}$ & $\begin{array}{c}\text { Flexible } \\
\text { Budget } \\
\text { (Based on } \\
\text { Actual (TRY) } \\
\text { H=(GXD) }\end{array}$ & $\begin{array}{l}\text { Budgeted } \\
\text { Variable Cost } \\
\text { Allocation } \\
\text { Rate (TRY/ } \\
\text { Min.) (G) }\end{array}$ & $\begin{array}{c}\text { Standard Cost } \\
\text { Driver (Min) } \\
\text { (I) }\end{array}$ & $\begin{array}{c}\text { Flexible } \\
\text { Budget (Based } \\
\text { on Standard } \\
\text { Quantity Of } \\
\text { Cost Driver) } \\
\text { (TRY) J=(GXI) }\end{array}$ & $\begin{array}{c}\text { Quantity } \\
\text { Variance } \\
\text { (TRY) } \\
(\mathrm{H}-\mathrm{J})\end{array}$ \\
\hline $\begin{array}{l}\text { Forest } \\
\text { Kebab }\end{array}$ & 0,0052 & 5940 & 30,89 & 0,0052 & 5280 & 27,46 & 3,43 \\
\hline $\begin{array}{c}\text { Pumpkin } \\
\text { Desert }\end{array}$ & 0,0052 & 3500 & 18,20 & 0,0052 & 3500 & 18,20 & 0,00 \\
\hline
\end{tabular}

Forest Kebab Standard cost driver assumed 5280 min. (8 min. unit $x 660$ Unit)

Pumpkin Desert. Standard cost driver assumed 3500 min. (5 min unit $x 700$ Unit)

Table 17 shows fixed and variable budget variances. Fixed budget variance is unfavorable on forest kebab. Actual fixed cost allocation rate and actual cost driver is higher than budgeted fixed cost allocation rate and budgeted cost driver. Thus, actual fixed activity cost exceeds budgeted fixed activity cost. On pumpkin desert, budgeted cost driver is higher than actual cost driver because of decreasing output level compared to budgeted. Also, budgeted fixed cost allocation rate is less than actual cost allocation rate. Thus, variance is favorable on pumpkin desert.

Table 17: Fixed Budget and Variable Budget Variances.

\begin{tabular}{|c|c|c|c|c|c|c|c|}
\hline \multicolumn{8}{|c|}{ Fixed Budget Variance } \\
\hline $\begin{array}{c}\text { Cost } \\
\text { Object }\end{array}$ & $\begin{array}{c}\text { Actual } \\
\text { Fixed Cost } \\
\text { Allocation } \\
\text { Rate (TRY/ } \\
\text { Min.) (K) }\end{array}$ & $\begin{array}{l}\text { Actual Cost } \\
\text { Driver } \\
(\mathrm{Min})(\mathrm{D})\end{array}$ & $\begin{array}{c}\text { Actual Fixed } \\
\text { Activity Cost } \\
\text { (TRY) } \\
\text { L=(KXD) }\end{array}$ & $\begin{array}{l}\text { Budgeted } \\
\text { Fixed Cost } \\
\text { Allocation } \\
\text { Rate (TRY/ } \\
\text { Min.) } \\
\text { (M) }\end{array}$ & $\begin{array}{l}\text { Budgeted } \\
\text { Cost Driver } \\
(\text { Min. })(\mathrm{N})\end{array}$ & $\begin{array}{c}\text { Budgeted } \\
\text { Fixed Activity } \\
\text { Cost (TRY) } \\
\mathrm{O}=(\mathrm{MXN})\end{array}$ & $\begin{array}{c}\text { Fixed Budget } \\
\text { Variance } \\
(\mathrm{TRY})(\mathrm{L}-\mathrm{O})\end{array}$ \\
\hline $\begin{array}{l}\text { Forest } \\
\text { Kebab }\end{array}$ & 0,1238 & 5940 & 735,37 & 0,1237 & 5760 & 712,51 & 22,86 \\
\hline $\begin{array}{c}\text { Pumpkin } \\
\text { Desert }\end{array}$ & 0,1238 & 3500 & 433,30 & 0,1237 & 3750 & 463,88 & $-30,58$ \\
\hline \multicolumn{8}{|c|}{ Variable Budget Variance } \\
\hline $\begin{array}{c}\text { Cost } \\
\text { Object }\end{array}$ & $\begin{array}{l}\text { Actual } \\
\text { Variable } \\
\text { Cost } \\
\text { Allocation } \\
\text { Rate (TRY/ } \\
\text { Min.) (E) }\end{array}$ & $\begin{array}{l}\text { Actual Cost } \\
\text { Driver } \\
\text { (Min.) (D) }\end{array}$ & $\begin{array}{c}\text { Actual } \\
\text { Variable } \\
\text { Activity } \\
\text { Cost (TRY) } \\
\mathrm{P}=(\mathrm{EXD})\end{array}$ & $\begin{array}{l}\text { Budgeted } \\
\text { Variable } \\
\text { Cost } \\
\text { Allocation } \\
\text { Rate (TRY/ } \\
\text { Min.) (G) }\end{array}$ & $\begin{array}{l}\text { Actual Cost } \\
\text { Driver (Min.) } \\
\text { (D) }\end{array}$ & $\begin{array}{c}\text { Flexible } \\
\text { Budget (Based } \\
\text { on Actual } \\
\text { Quantity } \\
\text { Of Cost } \\
\text { Driver) (TRY) } \\
\text { H=(GXD) }\end{array}$ & $\begin{array}{c}\text { Variable } \\
\text { Budget } \\
\text { Variance } \\
\text { (TRY) } \\
(\mathrm{P}-\mathrm{H})\end{array}$ \\
\hline
\end{tabular}




\begin{tabular}{|c|c|c|c|c|c|c|c|}
\hline $\begin{array}{l}\text { Forest } \\
\text { Kebab }\end{array}$ & 0,0054 & 5940 & 32,08 & 0,0052 & 5940 & 30,89 & 1,19 \\
\hline $\begin{array}{c}\text { Pumpkin } \\
\text { Desert }\end{array}$ & 0,0054 & 3500 & 18,90 & 0,0052 & 3500 & 18,20 & 0,70 \\
\hline
\end{tabular}

Table 18 shows spending, efficiency variances. Budgeted variable cost allocation rate is less than actual variable cost allocation rate. Thus, actual variable activity cost exceeds flexible budget. As a result spending variance is unfavorable for both foods.

Actual activity cost driver usage exceeds standard activitiy cost driver usage on forest kebab. Thus, efficiency variance is unfavorable.

Table 18: Spending, Efficiency, Budget and Capacity Variances.

\begin{tabular}{|c|c|c|c|c|c|c|c|}
\hline \multicolumn{8}{|c|}{ Spending (Price) Variance } \\
\hline $\begin{array}{c}\text { Cost } \\
\text { Object }\end{array}$ & $\begin{array}{c}\text { Actual } \\
\text { Variable } \\
\text { Cost } \\
\text { Allocation } \\
\text { Rate (TRY/ } \\
\text { Min.) (E) }\end{array}$ & $\begin{array}{l}\text { Actual Cost } \\
\text { Driver } \\
\text { (Min.) (D) }\end{array}$ & $\begin{array}{c}\text { Actual } \\
\text { Variable } \\
\text { Activity Cost } \\
\text { (TRY) } \\
\text { P=(EXD) }\end{array}$ & $\begin{array}{c}\text { Budgeted } \\
\text { Variable Cost } \\
\text { Allocation } \\
\text { Rate (TRY/ } \\
\text { Min.) (G) }\end{array}$ & $\begin{array}{c}\text { Actual Cost } \\
\text { Driver (Min.) } \\
\text { (D) }\end{array}$ & $\begin{array}{c}\text { Flexible } \\
\text { Budget (Based } \\
\text { on Actual } \\
\text { Quantity } \\
\text { Of Cost } \\
\text { Driver (TRY) } \\
\text { H=(GXD) }\end{array}$ & $\begin{array}{l}\text { Spending } \\
\text { Variance } \\
\text { (TRY) }(\mathrm{P}-\mathrm{H})\end{array}$ \\
\hline $\begin{array}{l}\text { Forest } \\
\text { Kebab }\end{array}$ & 0,0054 & 5940 & 32,08 & 0,0052 & 5940 & 30,89 & 1,19 \\
\hline $\begin{array}{c}\text { Pumpkin } \\
\text { Desert }\end{array}$ & 0,0054 & 3500 & 18,90 & 0,0052 & 3500 & 18,20 & 0,70 \\
\hline \multicolumn{8}{|c|}{ Efficiency Variance } \\
\hline $\begin{array}{l}\text { Cost } \\
\text { Object }\end{array}$ & $\begin{array}{l}\text { Budgeted } \\
\text { Variable } \\
\text { Cost } \\
\text { Allocation } \\
\text { Rate (TRY/ } \\
\text { Min.) (G) }\end{array}$ & $\begin{array}{l}\text { Actual Cost } \\
\text { Driver } \\
\text { (Min.) (D) }\end{array}$ & $\begin{array}{c}\text { Flexible } \\
\text { Budget } \\
\text { (Based } \\
\text { on Actual } \\
\text { Quantity of } \\
\text { Cost Driver) } \\
\text { (TRY) } \\
\text { H=(GXD) }\end{array}$ & $\begin{array}{c}\text { Budgeted } \\
\text { Variable Cost } \\
\text { Allocation } \\
\text { Rate (TRY/ } \\
\text { Min.) (G) }\end{array}$ & $\begin{array}{l}\text { Standard } \\
\text { Cost Driver } \\
(\text { Min) }(\mathrm{I})\end{array}$ & $\begin{array}{c}\text { Flexible } \\
\text { Budget (Based } \\
\text { on Standard } \\
\text { Quantity Of } \\
\text { Cost Driver) } \\
\text { (TRY) J=(GXI) }\end{array}$ & $\begin{array}{l}\text { Efficiency } \\
\text { Variance } \\
(\mathrm{TRY})(\mathrm{H}-\mathrm{J})\end{array}$ \\
\hline $\begin{array}{l}\text { Forest } \\
\text { Kebab }\end{array}$ & 0,0052 & 5940 & 30,89 & 0,0052 & 5280 & 27,46 & 3,43 \\
\hline $\begin{array}{c}\text { Pumpkin } \\
\text { Desert }\end{array}$ & 0,0052 & 3500 & 18,20 & 0,0052 & 3500 & 18,20 & 0,00 \\
\hline
\end{tabular}

Table 19 shows budget and capacity variances. Actual output level is higher than budgeted output level on forest kebab (see table 7). Thus, service activity budgeted fixed cost is less than actual fixed cost. Therefore, budget variance is unfavorable on forest kebap. Budgeted output level is higher than actual output level on pumpkin desert (see table 12). Thus, budged variance is favorable.

Capacity variance is unfavorable for two foods Capacity variance is a indicator for non-value added costs. In this framework, unfavorable variance refers availability of non-value added costs. In other 
words variance revealed that available capacity is not being fully used. This may lead to decrease in activity capacity in the long-run.

Table 19: Budget and Capacity Variance

\begin{tabular}{|c|c|c|c|c|c|c|c|}
\hline \multicolumn{8}{|c|}{ Budget Variance } \\
\hline Cost Object & $\begin{array}{c}\text { Actual } \\
\text { Fixed Cost } \\
\text { Allocation } \\
\text { Rate (TRY/ } \\
\text { Min.) (K) }\end{array}$ & $\begin{array}{c}\text { Actual } \\
\text { Cost } \\
\text { Driver } \\
\text { (Min.) (D) }\end{array}$ & $\begin{array}{c}\text { Actual Fixed } \\
\text { Activity Cost } \\
\text { (TRY) } \\
\text { L }=(\mathrm{KXD})\end{array}$ & $\begin{array}{c}\text { Budgeted } \\
\text { Fixed Cost } \\
\text { Allocation } \\
\text { Rate (TRY/ } \\
\text { Min.) (M) }\end{array}$ & $\begin{array}{l}\text { Budgeted } \\
\text { Cost } \\
\text { Driver }(\mathrm{N})\end{array}$ & $\begin{array}{c}\text { Budgeted } \\
\text { Fixed Activity } \\
\text { Cost (TRY) } \\
Q=(M-N)\end{array}$ & $\begin{array}{c}\text { Budget } \\
\text { Variance } \\
(\mathrm{TRY})(\mathrm{L}-\mathrm{Q})\end{array}$ \\
\hline Forest Kebab & 0,1238 & 5940 & 735,37 & 0,1237 & 5760 & 712,51 & 22,86 \\
\hline $\begin{array}{c}\text { Pumpkin } \\
\text { Desert }\end{array}$ & 0,1238 & 3500 & 433,30 & 0,1237 & 3750 & 463,88 & $-30,58$ \\
\hline \multicolumn{8}{|c|}{ Capacity Variance } \\
\hline Cost Object & $\begin{array}{l}\text { Budgeted } \\
\text { Fixed Cost } \\
\text { Allocation } \\
\text { Rate (TRY/ } \\
\text { Min.) (M) }\end{array}$ & $\begin{array}{l}\text { Budgeted } \\
\text { Cost } \\
\text { Driver } \\
(\mathrm{Min} .)(\mathrm{N})\end{array}$ & $\begin{array}{c}\text { Budgeted } \\
\text { Fixed } \\
\text { Activity Cost } \\
(\mathrm{TRY}) \\
\mathrm{Q}=(\mathrm{M}-\mathrm{N})\end{array}$ & $\begin{array}{c}\text { Budgeted } \\
\text { Fixed Cost } \\
\text { Allocation } \\
\text { Rate (TRY/ } \\
\text { Min.) (M) }\end{array}$ & $\begin{array}{l}\text { Standard } \\
\text { Cost } \\
\text { Driver } \\
\text { (Min.) (I) }\end{array}$ & $\begin{array}{c}\text { Flexible } \\
\text { Budget } \\
\text { (Based on } \\
\text { Standard } \\
\text { Quantity Of } \\
\text { Cost Driver) } \\
\text { (TRY) R(MXI) }\end{array}$ & $\begin{array}{c}\text { Capacity } \\
\text { Variance } \\
\text { (TRY) (Q-R) }\end{array}$ \\
\hline Forest Kebab & 0,1237 & 5760 & 712,51 & 0,1237 & 5280 & 653,14 & 59,38 \\
\hline $\begin{array}{c}\text { Pumpkin } \\
\text { Desert }\end{array}$ & 0,1237 & 3750 & 463,88 & 0,1237 & 3500 & 432,95 & 30,93 \\
\hline
\end{tabular}

Results revealed that variances are quite low. Price variance (Malcom, 1991), spending variances (Mak and Roush, 1994) and variable budget variances (Hansen and Mowen, 2006) generated similar results. Also, efficiency variance (Mak and Roush, 1994) and quantity variance (Malcom, 1991) results are equal. Because, calculations based on similar approaches.

\section{Conclusion}

Costing method is crucial to calculate true product cost especially in companies producing multiple products, labor-intensive and having high overhead. ABC assigns overheads to products via activity cost drivers, which are more convenient metrics determined within cause and effect relationship. Thus, $\mathrm{ABC}$ provides more accurate cost information compared to traditional costing methods. In this framework, $\mathrm{ABC}$ supports effective cost management and decision process and efficiency analysis with true and convenient data and encourages continuous improvement. Also, variance analysis is important process on cost management. Variance results should reveal variances for each activity and each cost object in activity based management environment. ABVA is compatible with logic of $\mathrm{ABC}$ and contribute to effective cost management in short and long term in $\mathrm{ABC}$ environment. 
Study aims to implement ABC and ABVA in food industry. Overheads assigned to foods by using $A B C$ method. Results revealed that overheads consist important part of food costs as mentioned before this characteristic shows that food industry is good candidate to apply ABC. ABC provides to understand root casuses of costs and efficiency analysis. Also, details provide to better control overheads to eliminate waste without decreasing service quality and to focus on creating more value. Also results provide to make profitability analysis for each food.

Variances are indicator for managers to adjust capacity and manage source of business productively. ABVA results revealed variances on activity and cost object level. Results indicated that variances resulted from dominantly difference between actual and forecasted output level. This difference caused to increase or decrease on activity level and affected to resource consumption and resource costs.

Study makes contribution literature on $\mathrm{ABC}$ and cost management in food industry. Study targets a self-service restaurant. Number and amount of overheads, activities, cost objects, may be differ from restaurant to restaurant. Thus, results cannot be generalize. This is limitation of the study.

\section{Author Contribution}

The authors made equal contributions to the literature review, data collection and analysis, interpretation of findings and conclusion part.

\section{Conflict of Interest}

The authors declared no potential conflicts of interest.

\section{Financial Support}

The authors have not received any financial support for this study.

\section{References}

Annaraud, K., Raab, C. \& Schrock, J. (2008). The Application Of Activity-Based Costing In A Quick Service Restaurant, Journal of Foodservice Business Research, 11(1), 23-44.

Ben Hadj Salem-Mhamdia, A., \& Bejar Ghadhab, B. (2012). Value Management And Activity Based Costing Model In The Tunisian Restaurant, International Journal of Contemporary Hospitality Management, $24(2,269-288$.

Cagwin, D. \& Bouwman W. (2002). The Association Between Activity-Based Costing And Improvement in Financial Performance, Management Accounting Research, 13(1), 1-39.

Cardoş, I.R. \& Pete,S. (2011). Activity-based Costing (FTM) and Activitybased Management (ABM) Implementation - Is This the Solution for Organizations to Gain Profitability?, Romanian Journal of Economics, 32 (1(41), 151-168. 
CIMA (2001). Activity based management - An overview, Technical briefing. Retrieved from https://www. cimaglobal.com/Documents/ImportedDocuments/ABM_techrpt_0401.pdf.

Cooper R. \& Kaplan R.S. (1988). Measure Costs Right: Make The Right Decisions, Harvard Business Review, 66, 96-103.

Cooper R. \& Kaplan, R.S. (1991). Profit Priorities From Activity-Based Costing, Harvard Business Review, 69(3), 130-135.

Cooper R. \& Kaplan, R.S. (1992). Activity-Based Systems: Measuring the Costs of Resource Usage, Accounting Horizons, September 1992, 1-12.

Geri, N. \& Ronen, B. (2005). Relevance Lost, The Rise And Fall of Activity-Based Costing, Human Systems Management, 24, 133-144.

Goebel, D.J., Marshal, G.W. \& Locandar, W.B. (1990). Accounting For A Market Orientation, Industrial Marketing Management, 27, 497-510.

Gupta, M. \& Galloway, K. (2003). Activity Based Costing/Management And Its Implications For Operation Management, Technovation, 23, 131-138.

Hansen, D. \& Mowen, M. (2006). Cost Management: Accounting And Control, Thomson South-Western, 5th ed., USA.

Hansen, D.R., Mowen, M.M. \& Guan, L. (2009). Cost Management: Accounting and Control, Cengage Learning, USA.

Horngren, C.T., Srikant, M.D. \& Rajan, M.V. (2012). Cost Accounting: A Managerial Emphasis, Prentice Hall, 14th ed.

Ittner, C. D. (1999). Activity Based Costing Concepts for Quality Improvement, European Management Journal, 17(5), 492-500.

Kaplan, R.S. \& Anderson, S.R. (2003). Time-Driven Activity-Based Costing, HBS Working Paper, No:04-45.

Kennedy, T. \& Affleck-Grawes, J. (2001). The Impact Of Activity-Based Costing In Firm Performance, Journal of Management Accounting Research, 13(1), 19-45.

Lere, C. J. (2000), Activity Based Costing: A Powerful Tool For Pricing, Journal of Business and Industrial Marketing, 15(1), 23-33.

Linassi, R., Alberton, A. \& Marinho, S.V. (2016). Menu Engineering And Activity Based Costing, International Journal of Contemprorary Hospitality Management, 28(7), 1417-1440.

Mak, Y.T \& Roush, M.L. (1994). Flexible Budgeting and Variance Analysis in an Activity-Based Costing Environment, Accounting Horizons, 8(2), 94-103.

Malcom, R. (1991), Overhead Control Implication of Activity Costing, Accounting Horizons, 5(4), 69-78.

Özbayrak, M. Akgün, M. \& Türker, A.K. (2004). Activity-Based Cost Estimation in Pussh/Pull Advanced Manufacturing Systems, International Journal of Production Economics, 87, 49-65.

Pazarçeviren, S.Y. \& Şahin, N.S. (2013). Activity-Based Direct Costing System in Determining Competitive Price, Balıkesir University The Journal of Social Sciences Institute, 16(29), 243-259.

Plowman, B. (2001). Activity Based Management: Improving Process and Profitability, Gower Publishing Limited, USA.

Raab, C. (2003). The Feasibility Of Activity-Based Costing In The Restaurant Industry, (Unpublished Doctoral Dissertation), University of Nevada, Nevada, USA.

Raab, C., Mayer, K., Ramdeen, C., \& Ng, S. (2005). The Application Of Activity-Based Costing In A Hong Kong Buffet Restaurant, International Journal of Hospitality and Tourism Administration,6(3), 11-26. 
Raab, C., Shoemaker, S. \& Mayer, K. J. (2007). Activity-Based Costing: A More Accurate Way To Estimate The Costs For Restaurant Menu, International Journal of Hospitality \& Tourism Administration, 8(3), 1-15.

Raab, C., Mayer, K. \& Shoemaker, S. (2009). Menu Engineering Using Activity-Based Costing: An Exploratory Study Using A Profit Factor Comparison Approach, Journal of Hospitality \& Tourism Research, 34(2), 204-224.

Raab, C. \& Zemke, D.M. (2016). Activity Based Costing In The Restaurant Industry: What's Past Is Prologue, The Journal of Hospitality Financial Management, 24(2), 133-146.

Sar1, E. (2015). Aplication Of Activity Based Costing Method And Activity Based Variance Analysis In A Manufacturing Company, (Unpublished Doctoral Dissertation), Istanbul University, Istanbul.

Sarı, E.S. \& Ülker, S.M. (2016). Variance Analyses In An Activitiy-Based Costing Environment And Its Application In A Manufacturing Company, Eurasian Business \& Economics Journal, 7, 32-49.

Stratton, W.O., Desroches, D., Lawson, R.A. \& Hatch, T. (2009). Activity-Based Costing: Is It Still Relevant?, Management Accounting Quarterly, 10(3), 31-40.

\section{Resume}

Zeliha KALDIRIM is Ph.D. candidate in Accounting, Social Sciences Institute, İstanbul University and accounting and finance teacher, Republic of Turkey Ministry of National Education. Her research interests focus on the areas of cost accounting, financial reporting standards.

Yusuf KALDIRIM, is accounting and finance teacher, Republic of Turkey Ministry of National Education. He holds a Ph.D. in Accounting and Finance from Marmara University. His research interests focus on the areas of cost management, management accounting, financial reporting standards. His research has appeared in The Journal of Accounting and Finance, Journal of Business Research-turk, Mali Çözüm Journal. 